\title{
Male and female entrepreneurs' employment growth ambitions: the contingent role of regulatory efficiency
}

\author{
Pourya Darnihamedani • Siri Terjesen
}

Accepted: 14 September 2020 / Published online: 7 October 2020

(C) The Author(s) 2020

\begin{abstract}
Entrepreneurs start and grow their ventures in a widely varying set of institutional contexts. One differentiator is a country's regulatory efficiency which encompasses the freedom to start and to run a business without excessive government interventions around registering, hiring, and firing employees, and price controls on currency. The efficiency of regulations varies substantially among countries and imposes additional costs and risks on entrepreneurs' activities. We integrate insights from institutional theory and recent literature on gender and entrepreneurship to better understand how a country's regulatory efficiency affects male and female entrepreneurs' employment growth ambitions. We explore three aspects of regulatory efficiency: business
\end{abstract}

Electronic supplementary material The online version of this article (https://doi.org/10.1007/s11187-020-00405-0) contains supplementary material, which is available to authorized users.

P. Darnihamedani $(\bowtie)$

Utrecht School of Economics, Utrecht University, Kriekenpitplein 21-22, 3584 EC Utrecht, The Netherlands

e-mail: p.darnihamedani@uu.nl

S. Terjesen

Department of Management Programs, College of Business, Florida Atlantic University, 777 Glades Road, Boca Raton, FL 33431, USA

e-mail: sterjesen@fau.edu

S. Terjesen

e-mail: siri.terjesen@nhh.no

S. Terjesen

Strategy and Management, Norwegian School of Economics, Helleveien 30, 5045 Bergen, Norway freedom (e.g., to start, operate, and close a venture), labor freedom (e.g., laws around minimum wage, layoffs, severance), and monetary freedom (e.g., price stability) using data from over 47,000 entrepreneurs in 68 countries. We find that entrepreneurs' growth ambitions are higher in countries with more efficient regulations, particularly those countries characterized by fewer labor law restrictions and greater monetary freedoms. These findings are further exacerbated by gender by such that, relative to their female counterparts, male entrepreneurs have significantly greater venture growth ambitions. Our paper contributes to the discussion on how formal institutions influence women and men entrepreneurs in distinct ways.

Keywords Female entrepreneurship · Formal institutions · Growth ambitions · Global Entrepreneurship Monitor · Economic freedom indicators

JEL classifications $\mathrm{J} 16 \cdot \mathrm{L} 26 \cdot \mathrm{L} 25$

\section{Introduction}

One of the world's fastest growing entrepreneurial populations is women-led new and small businesses (Brush et al. 2006; Brush and Cooper 2012) which number 274 million in 74 countries (Kelley et al. 2017). Compared to males, female entrepreneurs' growth ambitions remain low (or relatively low) across countries (Davis and Shaver 2012; Jennings 
and Brush 2013; Devine et al. 2019; Hechavarria et al. 2019), potentially leading to a waste of women's talents and capabilities (Coleman et al. 2019; Foss et al. 2019). Strikingly, according to Elam et al. (2019), there is no region in the world in which women entrepreneurs expect to grow their ventures more than men, and the gender gap is even more pronounced when examining entrepreneurs' high growth expectations. Existing literature highlights gender differences in entrepreneurship due to informal institutions, for example, differential effects on male and female entrepreneurs' social networks (e.g., Batjargal et al. 2013; Holmes et al. 2013; McAdam et al. 2019). There is a critical gap in our knowledge around how formal institutions may lead to differences in growth ambitions between female and male entrepreneurs (Estrin and Mickiewicz 2011; Bradley and Klein 2016; Terjesen et al. 2016; Welter et al. 2017).

Individual-level factors impact organizations, and these interactions lead to emergent, collective, and organizational-level outcomes, which may influence macro-level institutional determinants that lead to gender differences in entrepreneurs' growth ambitions (Shepherd et al. 2015; Bjornskov and Foss 2016; Welter et al. 2017). One overlooked institution that may explain entrepreneurial behavior is regulatory efficiency. Regulatory efficiency captures a country's level of business freedom (to start, operate, and close a business), labor freedom (e.g., laws around minimum wage, layoffs, severance), and monetary freedom (e.g., price stability). Efficient regulations decrease the costs imposed by regulations on entrepreneurs (e.g., legal registration, licensing, hiring and firing, inflation), thereby stimulating market entry and competition (North 1990; Baumol et al. 2007; McMullen et al. 2008; Shleifer 2010). Entrepreneurship research acknowledges the importance of regulatory efficiency to entrepreneurial activity, but has not explored gender differences (Estrin and Mickiewicz 2011; Goltz et al. 2015). We integrate insights from institutional theory, firm growth, and gender entrepreneurship to explore how labor market institutions shape female and male entrepreneurs' employment growth ambitions.

Our study offers three contributions. First, we respond to recent calls to investigate entrepreneurial diversity (e.g., Bjornskov and Foss 2010, 2016; Welter et al. 2017) by focusing on an important subgroup of entrepreneurs: female entrepreneurs. In addition to their contribution to economic growth and poverty reduction, female entrepreneurs, compared to male entrepreneurs, are more likely to contribute to their children's education, health, and nutrition (Kelley et al. 2017). Although women's entrepreneurship is an important issue from a policy perspective because there are significant benefits to encouraging and supporting women entrepreneurship, only $4 \%$ of gender and entrepreneurship studies address public policy (Link and Strong 2016). We tackle this gap in studies on gender and entrepreneurship by focusing on the influence of institutions on growth ambitions of female versus those of male entrepreneurs. Second, a rich literature utilizes transaction cost economics and new institutional economics perspectives (e.g., Baumol 1990; North 1990; Williamson 1996) to investigate how macro-level institutional factors may shape micro-level entrepreneurial behavior (Bowen and De Clercq 2008; Henrekson and Sanandaji 2011; Braunerhjelm and Eklund 2014). However, little is known about what mechanisms link these institutions to entrepreneurs' strategic decisions around hiring and growth (McMullen et al. 2008; Nikolaev et al. 2018; Chowdhury et al. 2019). We explore the mechanisms of one-off versus recurring costs imposed by regulations (Baumol et al. 2007; Darnihamedani et al. 2018) on gender differences among entrepreneurs (Watson and Robinson 2003; Alsos et al. 2006; Jennings and Brush 2013) that manifest in dissimilar impacts on employment growth ambitions of female versus male entrepreneurs. Moreover, we theoretically draw on the interplay of formal and informal institutions to examine the importance of formal institutions, and explain how the costs imposed by regulations interact with social expectations and perceptions (e.g., women's less risk taking propensity and lower levels of social capital than men) to lead to gender differences in entrepreneurs' growth ambitions. We argue that compared to women, regulatory efficiency is likely to positively influence male entrepreneurs' employment growth ambitions, as males typically have characteristics (e.g., higher risk propensity) and resources (e.g., extended networks of professionals and managers in the society) that are more easily activated by regulatory efficiency. Third, our study examines policy interventions to increase women's entrepreneurship (Arshed et al. 2014), especially given the ubiquitous nature of many regulations (Shleifer 2010). An essential step is examining whether formal institutions have differing impacts, and through which mechanisms, on female and male entrepreneurs' growth 
opportunities. Foss et al. (2019, p. 409) report that, despite an increase in the number of articles offering policy implications for female entrepreneurship, such policy implications are "mostly vague, conservative, and center on identifying skills gaps in women entrepreneurs that need to be fixed." Our study shows, potentially due to institutionalized gender gap (Tonoyan et al. 2020), even with higher levels of regulatory efficiency in a country, the gender gap in entrepreneurs' employment growth ambitions persists. Interestingly, with higher levels of regulatory efficiency, the gap is pronounced, showing that male entrepreneurs are more likely to benefit from efficient government regulations compared to female entrepreneurs.

The paper is structured as follows. Section 2 provides the theoretical background and develops hypotheses of this study accordingly. Section 3 explains the data, measures, and the empirical strategy. Section 4 presents the empirical results that correspond to the hypothesized relationships. Sections 5 and 6 discuss and conclude our findings, with implications for policy and practice, and directions for future research.

\section{Theoretical development and hypotheses}

\subsection{Employment growth ambitions of female versus} male entrepreneurs

A large literature explores gender differences in entrepreneurs' ambitions for their ventures, including employment growth. A few studies (e.g., Bardasi et al. 2011) report near-equal growth-oriented female and male-owned businesses; however, more studies report that early-stage female entrepreneurs, ceteris paribus, show lower employment growth ambitions than their male counterparts (e.g., Davis and Shaver 2012; Devine et al. 2019). Female entrepreneurs' lower employment growth may be driven by differences not only in terms of individual characteristics but also in terms of contextual factors, including informal (e.g., social expectations, stereotypes and biases, norms, cultural dimensions, and roles attributed to women and men) and formal (e.g., laws to protect more egalitarian child care, policies for reducing gender inequality) institutions in which they are embedded.

First, informal institutions may lead female entrepreneurs to form low employment growth ambitions compared to male entrepreneurs. Prior studies describe that certain characteristics more commonly found among women such as a higher fear of failure and lower risktaking propensity result from social expectations and norms (Sexton and Bowman-Upton 1990; Powell and Ansic 1997). Additionally, female entrepreneurs face greater hurdles in attracting resources needed for growth mainly due to widely held perceptions about women, and their capabilities and ventures (Brush et al. 2006; Ahl and Nelson 2015). Women are more likely to be structurally located in non-managerial and femaledominated positions, particularly in gender-segregated environments (Brush et al. 2019; Tonoyan et al. 2020). Such positions provide opportunities to accumulate entrepreneurship-specific resources as well as exposure to entrepreneurial opportunities. Women-led ventures tend to operate with lower levels of initial financing (Verheul and Thurik 2001; Fairlie and Robb 2009), lower levels of debt and equity beyond their nascent stages (Alsos et al. 2006), and less access to external financing such as venture capital and business angels due to investors' biases among other reasons (Coleman and Robb 2012; Kanze et al. 2018). Consistent with these arguments, prior studies suggest that female entrepreneurs are more likely than male entrepreneurs to pursue social missions (Verheul et al. 2005; Hechavarria et al. 2019) and consequently place less priority on growth and profitability (Davis and Shaver 2012). On the other hand, female entrepreneurs may have certain characteristics that may prove advantageous for survival and growth such as displaying stricter ethical codes, more discipline, and less reckless aggressive decisions than male entrepreneurs (Pan and Sparks 2012; van Staveren 2014).

Second, formal institutional arrangements shape not only the number of women (and men) exploring entrepreneurial opportunities and making strategic choices, but also in what ways these women form and realize growth ambitions (Brush et al. 2009; Thébaud 2015). We utilize both economic and management approaches to understanding how entrepreneurs both operate within controls and adopt to controls imposed by formal institutions (CuervoCazurra et al. 2019). That is, from an economics standpoint, stringent formal institutions limit market exchanges, and are quite explicit about the laws and regulations, and high-quality (i.e., market supporting) institutions facilitate market transactions; from a management standpoint, entrepreneurs can analyze, understand, and learn how to operate within institutional constraints (Cuervo-Cazurra et al. 2019). In this respect, formal institutions can set the "rules of the game" in such a way that male entrepreneurs 
have a high (or low) relative rewards for setting high employment growth ambitions compared to female entrepreneurs (Baumol 1990; North 1990; Estrin and Mickiewicz 2011). Through imposing additional risks and (one-off or recurring) costs, formal institutions may lead to gender differences in entrepreneurs' strategic and growth plans.

While both formal and informal institutions may distinctly influence entrepreneurs' aspirations and decisions, their interplay create an environment that shapes differences in female and male entrepreneurs' growth ambitions (North 1990; Williamson 1996; Terjesen et al. 2016; Bullough et al. 2017). Our theoretical development seeks to explain the importance of formal institutions and examine how the costs imposed by regulations interact with social expectations and perceptions (e.g., women's less risk-taking propensity and lower levels of social capital than men) lead to gender differences in entrepreneurs' growth ambitions.

\subsection{Regulatory efficiency}

Policy makers create regulations to endorse entrepreneurial entry, improve business growth, reduce fixed costs, access efficient technology, and lower demand constraints (Ardagna and Lusardi 2008; Ferraz et al. 2015). From a market efficiency perspective, the existence of regulations is justified to prevent market failure and when litigation is expensive, unpredictable, or biased (Shleifer 2010). Under these conditions, efficient (and detailed) contracts and (ill-functioning) courts cannot replace government regulations since, from costefficiency perspectives, contracts achieve less if their interpretation is unpredictable and their enforcement is costly (Shleifer 2010). That said, government regulations are designed to achieve the dual role of protecting society and keeping regulatory costs low. Hence, regulations are efficient when they protect society and citizens (e.g., workplace safety regulations, protection of vulnerable citizens) while imposing fewer costs and risks on entrepreneurs and businesses (Hart 2009).

A recent World Bank report explains that of five factors that can lead to inefficient regulations, three are relevant to entrepreneurship and growth. First, a lack of adequate information among actors resulting from poor governance results in additional costs and waste of time/ efforts among entrepreneurs (World Bank 2017). Second, a lack of coordination increases bureaucracy and red tape that may increase transaction costs to start and grow a business. Third, complex monitoring systems may create additional uncertainty and confusion among entrepreneurs. These three aspects of inefficient regulatory frameworks impose additional costs and risks on (growth-oriented) male and female entrepreneurs.

Regulations are a form of taxation that "make it difficult for entrepreneurs to create value" (Heritage Foundation 2008, p. 42). Efficient regulations protect society and citizens and impose as few costs as possible on starting and growing new ventures for entrepreneurs (Baumol et al. 2007; Gwartney et al. 2008; Shleifer 2010). While government regulations comprise various aspects of (business) activities in a society, regulatory efficiency describes the freedom to start and to run a business without excessive government intervention in the form of business legal registration (i.e., business freedom); the freedom to start employment and work where under any kind of conditions and for as long as that an individual is happy to accept (i.e., labor freedom); and a steady currency as a basis for exchange (i.e., monetary freedom) (Heritage Foundation 2008; McMullen et al. 2008; Kuckertz et al. 2016).

Although the raison d'etre of efficient regulations is reducing the costs imposed on entrepreneurs, we believe efficient regulations impose little costs on male compared to female entrepreneurs, thereby leading male entrepreneurs to form higher employment growth ambitions. First, with higher levels of regulatory efficiency, particularly start-up and license costs, government regulations impose less one-off entry costs on entrepreneurs (Darnihamedani et al. 2018; Branstetter et al. 2014). Low entry costs subsequently lead to excessive entry by imitative and less ambitious entrepreneurs, particularly among female entrepreneurs due to their engagement with social missions as well as less access to resources. Second and considering recurring costs imposed by regulations, male entrepreneurs have more access to financial and social capital than female entrepreneurs (Brush et al. 2004; Alsos et al. 2006). When regulations impose less (recurring) costs (i.e., higher levels of labor and monetary freedom), entrepreneurs will have more resources to set high employment growth ambitions since the availability of human and financial resources are related to growth (Penrose 1959; Heirman and Clarysse 2004; Khaire 2010). Male entrepreneurs are more likely to set higher employment growth ambitions than female entrepreneurs with lower (recurring) costs because, in addition to male entrepreneurs' access to more resources, they are more prone to 
uncalculated risk-taking and overconfidence (Watson and Robinson 2003; Jennings and Brush 2013). These two mechanisms suggest that, in a given country, male and female entrepreneurs do not equally benefit from efficient regulations. We focus on three pillars of regulatory efficiency-business freedom, labor freedom, monetary freedom - and how each pillar influences growth ambition of female and male entrepreneurs.

\subsection{Business freedom}

Business freedom captures the overall government regulation efficiency of starting, operating, and closing a business. One-off costs imposed by regulations mainly deter entry of imitative entrepreneurs and have little to no influence on entry by innovative and growth-oriented entrepreneurs (Kaplan et al. 2011; Branstetter et al. 2014) because growth-oriented innovative entrepreneurs have high expected returns on their ideas and enough start-up capital to incur such one-off costs (Darnihamedani et al. 2018). Higher levels of business freedom, due to imposing fewer one-off costs on potential entrepreneurs, stimulate the entry of imitative entrepreneurs given their lower expected returns on entrepreneurship (Kaplan et al. 2011; Rostam-Afschar 2014).

There are two key consequences of entry of imitative entrepreneurs for market dynamics and entrepreneurs' employment growth ambitions. First, with the presence of imitative entrepreneurs, the quality of "average" entrepreneurs in the market at least in terms of their employment growth ambitions decreases mainly because imitative entrepreneurs have lower employment growth ambitions than innovative entrepreneurs (Baumol et al. 2007; Parker 2018). Second, while imitative entrepreneurs stimulate competition in the product market (Welter et al. 2017), they simultaneously lower innovative entrepreneurs' employment growth expectations due to a lower ability to reap the fruits of innovation (van Stel et al. 2007; Darnihamedani et al. 2018). According to Schumpeter (1934), entrepreneurs innovate as they hope for (at least temporarily) monopoly position in the market, thereby providing a considerable profit opportunity. Imitation removes, at least partly, this opportunity by offering a similar product possibly with a lower price. Thus, imitation can subsequently discourage particularly innovative entrepreneurs from setting high ambitions for their future growth (Stam and Wennberg 2009). Hence, we propose:
Hypothesis 1a: Higher business freedom decreases entrepreneurs' employment growth ambitions.

There are two main reasons why higher levels of business freedom in a country will more detrimentally influence female entrepreneurs' employment growth ambitions than male entrepreneurs, related to dissimilar access to financing and to dissimilar risk-taking propensities, respectively. First, in a high business freedom environment, there is no or little selection effect such that female (and male) entrepreneurs with low expected returns for their ventures (and, hence, low employment growth ambitions) may decide to start a business (Watson and Robinson 2003; Darnihamedani et al. 2018). Since female entrepreneurs have, on average, lower growth ambitions relative to their male counterparts (Rosenbaum 2017; Pergelova et al. 2019), in the presence of high business freedom, the entry of female entrepreneurs with low growth ambitions would be disproportionally higher than those of male entrepreneurs with low growth ambitions. This is mainly driven by female entrepreneurs' lower access to investment and their tendency to launch ventures with lower levels of initial financing than less-ambitious male entrepreneurs (Boden and Nucci 2000; Alsos et al. 2006).

Second, in countries where formal institutions impose less business costs through business freedom, individuals with high-risk aversion may be motivated to start a business due to the lower costs of running and closing a business (Block and Landgraf 2016; Parker 2018). Female entrepreneurs have lower propensity for (uncalculated) risk-taking than male entrepreneurs (Sexton and Bowman-Upton 1990; Powell and Ansic 1997). With high levels of business freedom, we can expect that many potential female entrepreneurs may enter the market with low risk-taking propensities and, subsequently, with low levels of growth ambitions as entrepreneurial risk-taking is an important driver of growth ambitions. Taken together, we expect:

Hypothesis $1 b$ : The negative effect of business freedom on entrepreneurs' employment growth ambitions is stronger for female than for male entrepreneurs.

\subsection{Labor freedom}

Labor freedom includes various aspects related to the regulatory framework of a country's labor market such 
as minimum wages, laws inhibiting layoffs, severance requirements, and measurable regulatory restraints on hiring and hours worked (Heritage Foundation 2008). Stringent labor regulations impose recurring labor costs on entrepreneurs (Acemoglu 2001; Block et al. 2019), which negatively influence entrepreneurs' ability to invest in and to obtain financial and human resources which are essential to growth planning and ambitions (Penrose 1959; Heirman and Clarysse 2004; Estrin et al. 2016).

Additionally, a lack of labor freedom can restrict entrepreneurs' employment growth ambitions due to entrepreneurs' need for labor mobility (Coad et al. 2017; Block et al. 2019). Labor mobility helps entrepreneurs and young businesses to acquire essential (human) resources that are vital for growth (Eisenhardt and Martin 2000; Teece 2007). Moreover, when labor freedom is restricted through, for example, centralized collective bargaining, individuals are deterred from negotiating wages and allocating resources to their most productive activities (McMullen et al. 2008), subsequently limiting entrepreneurs' planning ability and autonomy to make optimal decisions for their ventures. In this environment, an entrepreneur cannot take decisions to maximize the growth opportunities of the venture even if he/she has high employment growth ambitions (Mueller and Thomas 2001). In this respect, restricted labor freedom may impose risks and restrictions on entrepreneurs' employment growth ambitions. Thus, we expect:

\section{Hypothesis 2a: Higher labor freedom increases entrepreneurs' employment growth ambitions.}

In a given country, there are two reasons why high levels of labor freedom have a more pronounced positive effect on male than on female entrepreneurs. First, since male entrepreneurs are more likely to start ventures with economic missions and high employment growth ambitions, men tend to have high expected returns on entrepreneurship (Watson and Robinson 2003; Verheul et al. 2005). In countries with low labor freedom, labor regulations impose considerable recurring labor costs (e.g., costs of hiring and firing) on entrepreneurs (Siebert 1997; Holmlund 2014). Male entrepreneurs are more sensitive to recurring costs imposed by regulations since they value economic missions and expected returns on entrepreneurship more than female entrepreneurs. Stringent regulations remove some of the expected "prize" of innovation and growth, particularly for male entrepreneurs.

Moreover, male entrepreneurs are more likely than female entrepreneurs to reap the fruits of labor mobility in a country with high labor freedom. One reason is that male entrepreneurs have, on average, more extensive networks of technical professionals and managers since the majority of professionals and managers are males, particularly in high-tech sectors with growth opportunities (Verheul and Thurik 2001; Devine et al. 2019). Females' social networks are less likely to overlap with technical professionals and managers (Devine et al. 2019). With labor mobility in a country, male entrepreneurs are more likely to acquire key human resources due to their social capital such as networks of managers and professionals. Another reason is that females tend to demonstrate more agreeableness (Vecchione et al. 2012), empathy, and cooperativeness rather than competition and aggression in the work environment and as entrepreneurs (Mainiero and Sullivan 2005). With high levels of labor mobility, which means rather effortless firing and hiring of individuals, these traits could impede female entrepreneurs' efforts to find and hire human capital as well as to fire employees who do not fit the venture goals and culture. In sum, when a country's institutions facilitate greater labor mobility, male entrepreneurs are best positioned to benefit by acquiring critical human capital required for growth:

Hypothesis 2b: The positive effect of labor freedom on entrepreneurs' employment growth ambitions is weaker for female than for male entrepreneurs.

\subsection{Monetary freedom}

Monetary freedom refers to price stability (i.e., inflation) and price control in a country (Friedman 1962; 1977). Higher values of monetary freedom can be achieved with little to no price control and a low rate of inflation (Heritage Foundation 2008). Inflation increases the costs of obtaining resources for entrepreneurs since a high inflation rate means high prices for resources such as technological, human, and financial resources (McMullen et al. 2008). Additionally, the concept and measurement of sound money is linked with a country's level of financial development and is an indicator of access to capital (Bjornskov and Foss 2010). Citizens' (including entrepreneurs') sound access to stable and 
predictable money can improve their access to external capital since investors are able to engage and make longterm calculations of the venture valuation (Bjornskov and Foss 2010; Kuckertz et al. 2016).

Through distorting prices, inflation imposes additional risks on entrepreneurs as it would be difficult for entrepreneurs to determine whether (and when) revenues exceed costs (DiLorenzo 2004). In this respect, entrepreneurs cannot precisely calculate the future market prices of their resources and are unable to make long-term growth plans since erratic inflation often "jams" the signaling effect of relative prices (Friedman 1977; Díaz-Casero et al. 2012). This effect is shown in prior studies such as Bjornskov and Foss (2010) and Nikolaev et al. (2018) who find strong positive effects of monetary freedom on opportunity entrepreneurship. Such additional risks caused by a lack of sound money in a country can deter the entry and survival of growthoriented entrepreneurs. Based on the above, we expect:

\section{Hypothesis 3a: Higher monetary freedom in- creases entrepreneurs' employment growth ambitions.}

Given male entrepreneurs' disproportional access to capital (Jennings and Brush 2013), these men are more likely to benefit from a country's access to sound money and lower rates of inflation. Although recent studies show that female entrepreneurs have certain advantages in managing venture capital, taking more calculated risks, and forming more productive relationships with investors (van Staveren 2014; Devine et al. 2019), male entrepreneurs have greater access to external sources such as venture capital and debt finance (Boden and Nucci 2000; Alsos et al. 2006). With higher levels of monetary freedom in a country, external financing is more widely available, particularly to male entrepreneurs (Becker-Blease and Sohl 2007; Coleman and Robb 2012; Jennings and Brush 2013).

Prior studies suggest that female entrepreneurs are more adept at making careful risk calculations for their ventures (Watson and Robinson 2003; van Staveren 2014). Low levels of monetary freedom distort prices of goods and services, making it more difficult for entrepreneurs to meticulously calculate business risks and make growth plans. Higher levels of monetary freedom predominantly help male entrepreneurs to set high employment growth ambitions compared to their female counterparts. Hence, we propose:
Hypothesis 3b: The positive effect of monetary freedom on employment growth ambitions of entrepreneurs is weaker for female than for male entrepreneurs.

\section{Data and methodology}

\subsection{Data collection and variables}

We utilize two datasets to investigate the relationship between regulatory efficiency factors and employment growth ambitions of male and female entrepreneurs. At the individual level, we use the Global Entrepreneurship Monitor (GEM) annual adult population survey, totaling 68 countries and 47,386 (early-stage) entrepreneurs from 2006 to 2013. The list of countries and the sample size per country can be found in the Online Appendix (Table A1). GEM is the world's leading entrepreneurship study and collects data and insights on entrepreneurs' human capital, attitudes, decisions, and employment growth ambitions (Reynolds et al. 2005). At the country level, we use Heritage Foundation data on the regulatory efficiency variables of business freedom, labor freedom, and monetary freedom, in line with recent entrepreneurship studies of economic freedom (McMullen et al. 2008; Valdez and Richardson 2013; Bradley and Klein 2016; Kuckertz et al. 2016).

The dependent variable, entrepreneurs' employment growth ambitions, is measured by an entrepreneur's expected job growth (employees) in 5 years. Mainly due to skewness of the data, we use a log-transformed version of the variable consistent with Hessels et al. (2008), Levie and Autio (2011), and Efendic et al. (2015). We measure the independent variables of business, labor, and monetary freedom with scores based on a myriad of factors. We incorporate a range of controls at country (e.g., GDP per capita, GDP growth rate, population) and individual (entrepreneur's current firm size by employees, university education, fear of failure, and age) levels. Table 1 details the variables' definition, measurement, data sources, and justification.

\subsection{Empirical strategy}

Consistent with prior research, we employ multi-level linear regressions with random intercepts at two levels: individual and country (Peterson et al. 2012; Stephan 
et al. 2015; Boudreaux et al. 2019). As entrepreneurs are nested in countries, multi-level regressions are designed to combine variables from several aggregation levels and reduce the likelihood of type 1 and type 2 errors by considering possible intra-class correlations (Hofmann et al. 2000). Multi-level models estimate variances of the random effects and use this information to give different weights to observations. Thus, multi-level models not only correct the standard errors, but also provide better estimations of coefficients.

Additionally, intra-class correlations (ICCs) determine that level 1 observations differ significantly from level 2 groups (Peterson et al. 2012). Existing literature applies various ICC cutoff points from 15 (Stephan et al. 2015) to 9.3\% (Boudreaux et al. 2019). Heck et al. $(2010$, p. 74$)$ argue that “ $\ldots$ if the ICC is quite small (i.e., researchers often use 0.05 as a rough 'cut-off' point), then there would be little advantage to conducting multi-level analysis." For our dependent variable of entrepreneurs' expected job growth, country-level ICC is around $7.5 \%$, providing the conditions to conduct multi-level regressions.

\section{Results}

As shown in Table 2, entrepreneurs currently create around 5 jobs and expect to provide 14 jobs in the next 5 years. Our sample is nearly equally split by gender: $54 \%$ male and $46 \%$ female. Some $42 \%$ of entrepreneurs attain some levels of university education and $41 \%$ report a fear of failure. At the country level, the average score of (lagged) business freedom, (lagged) labor freedom, and (lagged) monetary freedom are 66.4\%, 62.7\%, and $74.2 \%$ respectively. Moreover, the average (log) GDP per capita and GDP growth rate are 9.5 and $2.25 \%$. Looking at Table 2 correlations at the individual level, most are insignificant and low (below 0.2). At the country level, the correlations are higher for the main predictors, but never above 0.5 . Taken together, multicollinearity is not a concern in this study.

Table 3 model I shows that at the individual level, the current number of created jobs and high education has a significant positive relationship with entrepreneurs' employment growth ambitions. Entrepreneurs' employment growth ambitions have a significant negative relationship with fear of failure, but no relationship to age. At the country level, entrepreneurs' employment growth ambitions have a significant negative relationship with
GDP growth, but no relationship with a country's GDP per capita $(\log )$ and population $(\log )$.

Table 3 model II shows the direct effects of the three regulatory efficiency independent variables on entrepreneurs' employment growth ambitions. Employment growth ambitions have a significant negative relationship with lagged business freedom and a significant positive relationship with lagged labor freedom and lagged monetary freedom. These findings support hypotheses 1a, 2a, and 3a. However, when we distinguish between employment growth ambitions of male and female entrepreneurs, institutions show remarkable results.

The interaction terms in Table 3 model III demonstrate the aggregate effects of the moderator (i.e., male entrepreneurship). Yet, to analyze the gender difference (b) hypotheses more precisely, we look into interaction plots (Appendix). The first plot shows that in countries with extensive business freedom (i.e., values above 80 ), there is no significant difference in male and female entrepreneurs' employment growth ambitions. However, for moderate and low levels of business freedom (i.e., values equal or below 80 ), male entrepreneurs have a significantly higher (yet decreasing) level of employment growth ambition than do female entrepreneurs. This finding partially supports hypothesis $1 \mathrm{~b}$ (except for values above 80 ).

The second plot suggests that with higher levels of labor freedom (i.e., values above 40), male entrepreneurs form significantly higher employment growth ambitions than female entrepreneurs. However, for low levels of labor freedom (i.e., values equal to or lower than 40), the difference between male and female entrepreneurs is not significant. This finding is in line with hypothesis $2 b$. Concerning monetary freedom, Table 3's third plot shows the difference between male and female entrepreneurs' employment growth ambitions: only with high levels of monetary freedom (i.e., values equal to 70 or higher), male entrepreneurs have significantly higher employment growth expectations than their female counterparts; with monetary freedom values below 70 , the difference between male and female is not significant. This finding generally supports hypothesis $3 b$.

\subsection{Additional robustness checks}

To check the robustness of our results, we perform several additional tests. First, when we add interaction terms in a step-wise fashion, the main effects do not change. Second, to rule out the possibility of omitted 
Table 1 Independent and control variable definition, measurement, source, and justification

\begin{tabular}{|c|c|c|c|c|}
\hline Variable & Definition/justification & Measurement & Sources of data & $\begin{array}{l}\text { Justification (prior } \\
\text { studies) }\end{array}$ \\
\hline $\begin{array}{l}\text { Business } \\
\text { freedom } \\
\text { (lagged with } \\
1 \text { year) }\end{array}$ & $\begin{array}{l}\text { A country's freedom from the } \\
\text { burden of regulations on } \\
\text { starting, operating, and closing } \\
\text { business, given factors such as } \\
\text { time, cost and number of } \\
\text { procedures, and efficiency of } \\
\text { government in the regulatory } \\
\text { process }\end{array}$ & $\begin{array}{l}\text { The score is based on } 10 \text { factors, } \\
\text { all weighted equally: } \\
\text { Starting a business: procedures } \\
\text { (number); starting a business: } \\
\text { time (days); starting a business: } \\
\text { cost ( } \% \text { income per capita); } \\
\text { starting a business: minimum } \\
\text { capital ( } \% \text { income per capita); } \\
\text { obtaining a license: procedures } \\
\text { (number); obtaining a license: } \\
\text { time (days); obtaining a license: } \\
\text { cost ( } \% \text { income per capita); } \\
\text { closing a business: time (years); } \\
\text { closing a business: cost (\% of } \\
\text { estate); and closing a business: } \\
\text { recovery rate (cents on the dol- } \\
\text { lar) }\end{array}$ & World Bank Doing Business & $\begin{array}{l}\text { Gwartney et al. } \\
\text { (2008); } \\
\text { McMullen et al. } \\
\text { (2008); Aidis } \\
\text { et al. (2012) }\end{array}$ \\
\hline $\begin{array}{l}\text { Labor freedom } \\
\text { (lagged } \\
1 \text { year) }\end{array}$ & $\begin{array}{l}\text { A country's freedom from legal } \\
\text { regulation on the labor market, } \\
\text { including those relating to } \\
\text { minimum wages, hiring and } \\
\text { firing, hours of work, and } \\
\text { severance requirements }\end{array}$ & $\begin{array}{l}\text { Six quantitative factors equally } \\
\text { weighted at one-sixth: } \\
\text { Ratio of minimum wage to the } \\
\text { average value added per } \\
\text { worker; hindrance to hiring } \\
\text { additional workers; rigidity of } \\
\text { hours; difficulty of firing } \\
\text { redundant employees; legally } \\
\text { mandated notice period; and } \\
\text { mandatory severance pay }\end{array}$ & $\begin{array}{l}\text { In order of priority: World Bank } \\
\text { Doing Business; Economist } \\
\text { Intelligence Unit, Country } \\
\text { Commerce (2009)-2012; U.S. } \\
\text { Dept. of Commerce, Country } \\
\text { Commercial Guide } \\
\text { (2009)-2012; and each } \\
\text { country's official government } \\
\text { publications }\end{array}$ & $\begin{array}{l}\text { Aidis et al. (2012); } \\
\text { Bjornskov and } \\
\text { Foss (2010); } \\
\text { McMullen et al. } \\
\text { (2008) }\end{array}$ \\
\hline $\begin{array}{l}\text { Monetary } \\
\text { freedom } \\
\text { (lagged } \\
1 \text { year) }\end{array}$ & $\begin{array}{l}\text { A country's freedom from price } \\
\text { controls, and includes a } \\
\text { measure of price stability. Both } \\
\text { inflation and price controls } \\
\text { distort market activity }\end{array}$ & $\begin{array}{l}\text { The weighted average inflation } \\
\text { rate for the most recent } 3 \text { years } \\
\text { serves as the primary input into } \\
\text { an equation that generates the } \\
\text { base score for monetary } \\
\text { freedom. } \\
\text { The extent of price controls is then } \\
\text { assessed as a penalty of up to } 20 \\
\text { points subtracted from the base } \\
\text { score }\end{array}$ & $\begin{array}{l}\text { In order of priority: International } \\
\text { Monetary Fund (IMF), } \\
\text { International Financial Statistics } \\
\text { Online; IMF, World Economic } \\
\text { Outlook, 2012; Economist } \\
\text { Intelligence Unit, ViewsWire; } \\
\text { and each country's official } \\
\text { government publications }\end{array}$ & $\begin{array}{l}\text { Bjornskov and Foss } \\
\text { (2008); Nystrom } \\
\text { (2008); Aidis } \\
\text { et al. (2012); } \\
\text { Kuckertz et al. } \\
\text { (2014) }\end{array}$ \\
\hline GDP per capita & $\begin{array}{l}\text { GDP per capita indicates a } \\
\text { country's level of economic } \\
\text { development }\end{array}$ & GDP per capita & $\begin{array}{l}\text { World Bank Development } \\
\text { Indicators (WBDI) }\end{array}$ & $\begin{array}{l}\text { Danakol et al. } \\
\text { (2017); } \\
\text { Boudreaux et al. } \\
\text { (2019) }\end{array}$ \\
\hline $\begin{array}{l}\text { GDP growth } \\
\text { rate }\end{array}$ & $\begin{array}{l}\text { GDP growth rate indicates } \\
\text { economic growth and the } \\
\text { creation of opportunities at the } \\
\text { macro-level }\end{array}$ & GDP growth rate & WBDI & $\begin{array}{l}\text { Wong et al. (2005); } \\
\text { Autio and Fu } \\
\text { (2015) }\end{array}$ \\
\hline Population & $\begin{array}{l}\text { Country population indicates size } \\
\text { and possibilities for innovation } \\
\text { and entrepreneurship at the } \\
\text { macro-level }\end{array}$ & Population & WBDI & $\begin{array}{l}\text { Reynolds et al. } \\
\text { (2005); Autio } \\
\text { et al. (2013) }\end{array}$ \\
\hline $\begin{array}{l}\text { Current } \\
\text { number of } \\
\text { created jobs }\end{array}$ & $\begin{array}{l}\text { Current firm size is an important } \\
\text { driver of firm growth and } \\
\text { survival. }\end{array}$ & $\begin{array}{l}\text { Current venture size by number of } \\
\text { employees who work (full-time } \\
\text { and part-time) }\end{array}$ & $\begin{array}{l}\text { Global Entrepreneurship } \\
\text { Monitor (GEM) }\end{array}$ & $\begin{array}{l}\text { Coad et al. (2017); } \\
\text { Daunfeldt et al. } \\
\text { (2015) }\end{array}$ \\
\hline $\begin{array}{l}\text { Entrepreneur's } \\
\text { university } \\
\text { education }\end{array}$ & $\begin{array}{l}\text { Formal education, as a proxy of } \\
\text { investment in human capital, is } \\
\text { a driver of entrepreneurs' } \\
\text { performance and success }\end{array}$ & $\begin{array}{l}\text { Dummy: } 1 \text { if university education } \\
\text { and } 0 \text { otherwise }\end{array}$ & GEM & $\begin{array}{l}\text { Unger et al. (2011); } \\
\text { Estrin et al. } \\
\text { (2016) }\end{array}$ \\
\hline Fear of failure & $\begin{array}{l}\text { Fear of failure, as a proxy of the } \\
\text { risk-taking attitude, is a driver }\end{array}$ & $\begin{array}{l}\text { Dummy: } 1 \text { if yes and } 0 \text { if otherwise } \\
\text { response to "fear of failure }\end{array}$ & GEM & \\
\hline
\end{tabular}


Table 1 (continued)

\begin{tabular}{|c|c|c|c|c|}
\hline Variable & Definition/justification & Measurement & Sources of data & $\begin{array}{l}\text { Justification (prior } \\
\text { studies) }\end{array}$ \\
\hline & $\begin{array}{l}\text { of entrepreneurs' ambitions and } \\
\text { attitude toward growth }\end{array}$ & $\begin{array}{l}\text { would prevent you from starting } \\
\text { a business" }\end{array}$ & & $\begin{array}{l}\text { Sternberg and } \\
\text { Wennekers } \\
(2005)\end{array}$ \\
\hline $\begin{array}{l}\text { Entrepreneur's } \\
\text { age }\end{array}$ & $\begin{array}{l}\text { Men and women start } \\
\text { entrepreneurial activity at } \\
\text { different life stages }\end{array}$ & Respondent age in years & GEM & $\begin{array}{l}\text { Darnihamedani } \\
\text { et al. (2018); } \\
\text { Boudreaux et al. } \\
\text { (2019) }\end{array}$ \\
\hline $\begin{array}{l}\text { Entrepreneur's } \\
\text { gender }\end{array}$ & Biological sex & Dummy: 1 if male and 0 if female & GEM & $\begin{array}{l}\text { Darnihamedani } \\
\text { et al. (2018); } \\
\text { Boudreaux et al. } \\
\text { (2019) }\end{array}$ \\
\hline
\end{tabular}

variable bias at least to some extent (Boudreaux et al. 2019), we add several country- and individual-level controls, in addition to industry dummies that might influence results (Online Appendix, Table A2). At the country-level, several formal institutional variables (i.e., access to credit, corporate tax rate, collected social security contributions, protection of property rights), two culture variables (i.e., uncertainty avoidance, collectivism), and several important socioeconomic (i.e., population growth, developing versus developed, economy size (proxied by GDP), labor with tertiary education, GDP per capita squared) in line with prior studies (Levie and Autio 2011; Autio et al. 2013; Efendic et al. 2015; Li et al. 2018). Since our sample is only 68 countries, we add and replace country-level control variables one-by-one, and the results are consistent with our main findings. Third, at the individual level, other relevant control variables including perceived social status of the entrepreneur, recent entrepreneurship experience, entrepreneurial networks, and perception of entrepreneurial skills (Koellinger et al. 2007; Ucbasaran et al. 2010; Estrin et al. 2013) do not change results (Online Appendix, Table A2 for more details).

Table 2 Descriptive statistics and correlation matrix of the individual- and country-level variables

\begin{tabular}{|c|c|c|c|c|c|c|c|c|c|c|c|c|c|}
\hline Variables & Mean & SD & 1 & 2 & 3 & 4 & 5 & 6 & 7 & 8 & 9 & 10 & 11 \\
\hline \multicolumn{14}{|l|}{ Individual-level variables } \\
\hline $\begin{array}{l}\text { 1. Entrepreneurs' growth } \\
\text { ambition }\end{array}$ & 10.17 & 428.85 & & & & & & & & & & & \\
\hline $\begin{array}{l}\text { 2. Current number of created } \\
\text { jobs }\end{array}$ & 5.29 & 40.31 & -0.45 & & & & & & & & & & \\
\hline $\begin{array}{l}\text { 3. Entrepreneurs' university } \\
\text { education }\end{array}$ & 0.42 & 0.49 & 0.04 & 0.02 & & & & & & & & & \\
\hline 4. Fear of failure & 0.41 & 0.62 & 0.03 & 0.05 & 0.01 & & & & & & & & \\
\hline 5. Age of entrepreneur & 41.92 & 14.71 & 0.02 & 0.03 & 0.07 & 0.04 & & & & & & & \\
\hline $\begin{array}{l}\text { 6. Gender of entrepreneur } \\
\text { (male) }\end{array}$ & 0.54 & 0.45 & 0.08 & -0.01 & 0.03 & -0.06 & -0.01 & & & & & & \\
\hline \multicolumn{14}{|l|}{ Country-level variables } \\
\hline 7. Lagged business freedom & 66.37 & 14.91 & -0.08 & -0.04 & 0.19 & 0.01 & 0.20 & 0.02 & & & & & \\
\hline 8. Lagged labor freedom & 62.73 & 15.70 & 0.10 & 0.05 & 0.11 & -0.02 & 0.09 & 0.01 & 0.33 & & & & \\
\hline 9. Lagged monetary freedom & 74.24 & 7.63 & 0.04 & 0.04 & 0.08 & 0.02 & 0.12 & -0.01 & 0.44 & 0.28 & & & \\
\hline 10. Population $(\log )$ & 17.25 & 1.60 & 0.00 & 0.01 & -0.05 & 0.02 & -0.03 & -0.03 & -0.32 & 0.16 & -0.06 & & \\
\hline 11. GDP per capita $(\log )$ & 9.57 & 1.12 & 0.00 & 0.04 & 0.25 & 0.03 & 0.25 & 0.06 & 0.35 & 0.11 & 0.39 & -0.18 & \\
\hline 12. GDP growth rate & 2.25 & 3.78 & 0.03 & -0.03 & -0.12 & -0.05 & -0.12 & -0.03 & -0.34 & 0.03 & -0.12 & 0.21 & -0.46 \\
\hline
\end{tabular}


Table 3 Employment growth ambitions of entrepreneurs (log-transformed)

\begin{tabular}{|c|c|c|c|}
\hline Variables & Model I & Model II & Model III \\
\hline \multicolumn{4}{|l|}{ Individual level } \\
\hline Entrepreneur's university education & $0.195 * *(0.010)$ & $0.193 * *(0.010)$ & $0.192 * *(0.010)$ \\
\hline Entrepreneur's fear of failure & $-0.036 * *(0.007)$ & $-0.037 * *(0.007)$ & $-0.037 * *(0.007)$ \\
\hline Entrepreneur's gender (male) & $0.226^{* *}(0.009)$ & $0.227 * *(0.010)$ & $0.022(0.104)$ \\
\hline Entrepreneur's age & $-0.002(0.002)$ & $-0.003(0.002)$ & $-0.003(0.002)$ \\
\hline Age square & $-0.00001(0.00002)$ & $-0.00001(0.00002)$ & $-0.00001(0.00002)$ \\
\hline Current number of created jobs & $0.001 * *(0.0001)$ & $0.001 * *(0.0001)$ & $0.001 * *(0.0001)$ \\
\hline Year dummies & Yes & Yes & Yes \\
\hline \multicolumn{4}{|l|}{ Country characteristics } \\
\hline GDP per capita (log) & $-0.024(0.020)$ & $-0.025(0.027)$ & $-0.023(0.027)$ \\
\hline GDP growth rate & $-0.008 * *(0.002)$ & $-0.007 * *(0.002)$ & $-0.007 * *(0.003)$ \\
\hline Population $(\log )$ & $-0.024(0.020)$ & $-0.023(0.021)$ & $-0.022(0.021)$ \\
\hline Lagged business freedom $(H 1 a)$ & & $-0.002 * *(0.0008)$ & $0.0003(0.009)$ \\
\hline Lagged labor freedom $(H 2 a)$ & & $0.003 * *(0.0007)$ & $0.0002(0.0008)$ \\
\hline Lagged monetary freedom $(H 3 a)$ & & $0.005^{* *}(0.001)$ & $0.003(0.002)$ \\
\hline Lagged business freedom * male entrepreneurship $(H 1 b)$ & & & $-0.003 * *(0.0007)$ \\
\hline Lagged labor freedom * male entrepreneurship $(H 2 b)$ & & & $0.003 * *(0.0006)$ \\
\hline Lagged monetary freedom* male entrepreneurship $(H 3 b)$ & & & $0.003 *(0.001)$ \\
\hline Number of countries & 68 & 68 & 68 \\
\hline Number of entrepreneurs & 47,386 & 47,386 & 47,386 \\
\hline Country-level ICC & 0.076 & 0.078 & 0.079 \\
\hline LR tests & $* *$ & $* *$ & $* *$ \\
\hline
\end{tabular}

$* p<0.05$ and $* * p<0.01$ (standard beta coefficients and standard errors presented)

\section{Discussion}

Our results support the conclusion that the efficiency of macro-level government regulations influences both male and female entrepreneurs' micro-level employment growth ambitions. While business regulations (e.g., starting, obtaining permissions, closing a business) deter entry by less ambitious entrepreneurs, stringent and inefficient labor and monetary regulations decrease all entrepreneurs' employment growth ambitions. Our findings are, by and large, consistent with prior entrepreneurship and institutional economics studies (Estrin et al. 2013; Nikolaev et al. 2018; Chowdhury et al. 2019). Yet, our results suggest that institutions may have diverging effects on subgroups of entrepreneurs (i.e., ambitious versus less ambitious entrepreneurs, men versus women entrepreneurs) since (high quality) institutions are not equally available to all economic agents (Aparicio et al. 2016). Policy makers who set regulations with the goal of protecting citizens (e.g., the unemployed) unintentionally create a situation where subgroups of entrepreneurs are advantaged (or disadvantaged) in terms of access to resources as well as expected returns on their ventures (Baumol et al. 2007).

More specifically and considering the first independent variable, i.e., business freedom, we find a significant negative direct effect on entrepreneurs' employment growth ambitions. Thus, there is evidence for the importance of one-off entry costs imposed by regulations on entrepreneurs, albeit in a cross-country perspective. This is in line with Darnihamedani et al.'s (2018) country-level cross-sectional findings that reports moderate effects of start-up costs as an important one-off cost on innovative entrepreneurship in a country. While there are changes in the levels of business freedom across countries, one possible explanation is that oneoff entry costs may impose a selection effect on the type of entrepreneurs entering the market in addition to other, probably more long-term effects from, for example, informal institutions such as norms and culture (Ahl and Nelson 2015; Eesley 2016). However, our findings show that for moderate and lower levels of business 
freedom (i.e., values equal or below 80), male entrepreneurs have a significantly higher (yet decreasing) levels of employment growth ambition than do female entrepreneurs. The decreasing aspect of male entrepreneurs' employment growth ambitions is interesting to observe since, with high levels of business freedom, there is little to no significant gender gap in entrepreneurs' employment growth ambitions. Recent studies suggest that start-up ease perceptions can influence the gender gap in entrepreneurial entry (Tonoyan et al. 2020). High levels of business freedom can influence the perception of straightforward start-up procedures and low barriers for entry. This is particularly important for female entrepreneurs due to their lower expected returns on entrepreneurship and less access to resources (Watson and Robinson 2003).

Taken together, our findings show the importance of recurring costs imposed by regulations on male and female entrepreneurs' employment growth ambitions, consistent with prior studies (Baumol et al. 2007; Darnihamedani et al. 2018). We find that labor freedom positively influences entrepreneurs' employment growth ambitions, particularly among males. The second plot in Appendix (Fig. 1) shows that while both male and female entrepreneurs' employment growth ambitions rise with higher levels of labor freedom, male entrepreneurs' employment growth ambitions rise more sharply. These findings are in line with our argument that labor freedom offers certain advantages for entrepreneurs' employment growth ambitions such as labor mobility and lower labor costs (Siebert 1997; Holmlund 2014; Kuckertz et al. 2016). These advantages considerably increase entrepreneurs' access to resources and expected returns on business growth that are important determinants for growth and planning (Penrose 1959; Autio and Acs 2010; Khaire 2010). That said, we argue that male entrepreneurs are better positioned than female entrepreneurs to benefit from the advantages of labor freedom. As male entrepreneurs are driven more by economic missions and monetary reasons than female entrepreneurs (Sexton and Bowman-Upton 1990; Verheul et al. 2005), males are more likely to have venture ambitions and to engage with growth planning. Among males, return on entrepreneurship plays a pivotal role in engagement in growth activities and for assuming innovation and growth risks. Thus, if regulations impose less recurring labor costs on entrepreneurs, male entrepreneurs are more likely to be engaged with growth and innovation (van Stel et al. 2007; Darnihamedani et al. 2018). Male entrepreneurs have a more extended network of managers, tech professionals, and investors than female entrepreneurs (Verheul and Thurik 2001; Devine et al. 2019). Such an extended network, in environments characterized by high levels of labor freedom, can help with hiring and retaining talent, needed for growth, as well as with finding monetary resources for acquiring human and non-human capital. All of these factors lead to better growth prospects and higher employment growth ambitions among male entrepreneurs particularly when a country's labor regulations are flexible.

Monetary freedom results generally resemble labor freedom and are in line with the recurring cost argument. Here, we see that monetary freedom positively contributes to employment growth ambitions, particularly for male entrepreneurs who, in turn, can create or widen the gender gap in a country's growth-oriented entrepreneurship. There are three specific reasons why male entrepreneurs are better positioned than female entrepreneurs to take advantage of monetary freedom: first, due to male entrepreneurs' growth appetite and economic missions, males deem expected returns on entrepreneurship more decisively than their female counterparts (Verheul et al. 2005; Hechavarria et al. 2019). High recurring costs imposed by inflation (e.g., high prices of resources) and lack of access to sound money lower male entrepreneurs' expected returns and may result in lower growth appetites. Secondly, a country's variability of inflation may impose additional risks, particularly on male entrepreneurs. Since female entrepreneurs are less prone to reckless and aggressive decisions (Robinson and Watson 2003; Jennings and Brush 2013), they are more able to cope with variability of inflation and price fluctuations. Male entrepreneurs, however, may find it more challenging to plan for growth in times of volatile inflation and fluctuating prices as they are less able to make a "realistic" judgment of their venture potentials and needs (Jennings and Brush 2013). Lastly, while male entrepreneurs rely on external financing such as venture capital more than female entrepreneurs, access to sound money persuades the (foreign direct) investments into a country including venture capital investments (Bjornskov and Foss 2010; Nikolaev et al. 2018). These arguments show that recurring costs of inefficient regulations have more detrimental effects on male entrepreneurs.

Our findings support the notion that the dynamics of male versus female entrepreneurs' employment growth ambitions differ significantly. Our analysis across both developed and developing countries reveals that female entrepreneurs have lower growth appetite than their male 
counterparts. Extant entrepreneurship research largely focuses on a few new fast-growing entrepreneurs and their antecedents, growth processes, and influences at firm and societal levels (Bradley and Klein 2016; Fisher et al. 2017; Welter et al. 2017). Our results show that female entrepreneurs have, ceteris paribus, lower employment growth ambitions possibly due to their lower growth "possibilities" such as less access to human, social, and financial capital than male entrepreneurs (Alsos et al. 2006; Coleman and Robb 2012). Our argument is simply that, due to various reasons, it may also be less "desirable" for female entrepreneurs to engage with high employment growth ambitions along their journey. The "desirability" and "possibility" aspects of growth could be due to behavioral reasons such as socially driven missions and a reached reference point (Tversky and Kahneman 1992) or due to external factors such as female entrepreneurs' difficulty in accessing resources.

\section{Conclusions}

Our study unpacks entrepreneurial activity by exploring gender differences in entrepreneurs' growth ambitions. Despite the positive overall influence of regulatory efficiency on entrepreneurship, the gap in employment growth ambitions of female versus male entrepreneurs persists particularly when labor and monetary freedom are present. Interestingly, the gender gap is particularly pronounced in countries with higher levels of regulatory efficiency. Our analysis provides a basis for understanding how the interplay of formal and informal institutions creates an environment, even in countries with highquality institutions, that does not help (or provide very little help) to close the gender gap in entrepreneurship. By presenting our arguments and findings, we hope to stimulate further inquiries into the linkages between formal institutions, entrepreneurship policies, informal institutions, and the entrepreneurial decisions and behavior of women and men. Below, we offer implications, limitations, and directions for future research.

\subsection{Implications}

To date, little scholarly attention has been devoted to the influence of costs imposed by regulations on women versus men entrepreneurship given the dearth of gender and entrepreneurship studies that consider public policy (Link and Strong 2016). Prior studies do not typically consider regulations as sources of costs that may influence women entrepreneurs differently from men entrepreneurs given their differences in the society. Prior studies investigated the sources of women and men entrepreneurs' differences from the perspective of informal institutions such as dissimilar access to social capital, access to capital and social norms, and expectations (Powell and Ansic 1997; Kanze et al. 2018; Tonoyan et al. 2020). Yet, it has been unclear how the interplay of such differences arising from informal institutions and regulatory costs originating from formal institutions shape women entrepreneurs' growth ambitions. Our study sheds light on this gap. Our main argument premised on the notion that male entrepreneurs are overall better positioned than female entrepreneurs to benefit from efficient regulations. In this context, the government, through (re-)structuring the relative rewards for entrepreneurship (Baumol 1990) in the society, can stimulate ambitious entrepreneurship among females by using appropriate business regulations.

Our findings suggest several policy implications as we identify important differences between one-off costs (institutions of business freedom) and recurring costs (institutions of labor and monetary) on growth ambitions of women and men entrepreneurs. First and concerning one-off entry costs stemming from (lack of) business freedom, ambitious men entrepreneurs are more likely to incur such costs to start their businesses than are ambitious women entrepreneurs as a result of gender differences in the society. Reducing one-off entry costs through business freedom seems to lessen, and eventually close, the gender gap in the sense that men entrepreneurs witness sharp declines in growth ambitions but women entrepreneurs only witness minor declines in growth ambitions (Appendix Fig. 1). This finding suggests that policy makers should carefully consider the consequences of higher levels of business freedom in a country.

Second, both men and women entrepreneurs view stringent labor and monetary regulations as recurring costs that repeatedly reduce their incomes and limit their access to resources (Baumol et al. 2007). These recurring costs discourage both men and women entrepreneurs equally from setting high growth ambitions in the market while having more detrimental effects on men entrepreneurs. On the other hand, when countries score high on labor and monetary freedom, men entrepreneurs benefit disproportionally, possibly due to their social capital as well as their economic ambitions. Policy makers, while advocating labor and monetary freedom, should design 
specific women's entrepreneurship policies that systematically tackle such inequalities in a country. In many countries, women's entrepreneurship policies can provide resources much needed by ambitious women entrepreneurs, e.g., in terms of subsidies, grants, networking events, and education. While such policies help to reduce the gender gap, they appear insufficient and slow to close the gender gap in terms of the quality (or ambitions) of entrepreneurs. One policy solution is encouraging women to enter more into decision-making positions in entrepreneurial ecosystems such as investment and advisory firms, accelerators, and incubators (Brush et al. 2019; Sperber and Linder 2019). Such women decision-makers are more likely to provide support and resources for survival and growth of women entrepreneurs in the society.

Third, we suggest that policymakers support "enablers" of women entrepreneurship in the society such as role models and women institutional entrepreneurs (Garud et al. 2007; Levie and Autio 2011). Female role models and institutional entrepreneurs can, through a bottom-up approach, not only contribute to transforming informal institutions (i.e., existing norms and values), but also help to adjust entrepreneurship policies so that such policies provide more equal grounds for growth opportunities and resources for women entrepreneurs. The female entrepreneurship literature acknowledges the need for a critical mass of female players in traditionally male-dominated positions to support women entrepreneurs to change existing formal rules and informal norms and values (Brush et al. 2009).

\subsection{Limitations}

Before concluding, we acknowledge several limitations. First, the eight-year cross-sectional nature is certainly not long enough to investigate the impact of institutional development on entrepreneurs' employment growth ambitions. A longitudinal study in which male and female entrepreneurs may vary with institutional change in a country can substantially help to derive causality (Smith and Miner 1983; Lechner and Kreutzer 2010). The GEM time horizon is still short to explore institutional changes in a country (Estrin et al. 2013). Longer-term studies show how pro-market reforms increase private firm performance in developing countries (Lau 2012) and should be explored using a larger GEM dataset. Although we added several robustness checks to address endogeneity, we can only partially address the timeline issue. Second, there may be other moderators affecting the relationship between efficient regulations and employment growth ambitions. Future studies should explore individual characteristics (e.g., entrepreneurs' networks, human capital, and fear of failure) and resource access (e.g., financial resources). For example, venture capital financing may influence employment growth ambitions as venture capitalists offer better linkages to financial capital and nonfinancial resources (Aghion et al. 2007; Grilli and Murtinu 2014). Future studies can investigate whether government regulations influence growth ambitions of female entrepreneurs who are backed by venture capitalists compared to those who are not since inefficient regulations in the form of high recurring costs may more severely impact non-venture-capital-backed female entrepreneurs due to their limited access to resources (Cassar 2004; Darnihamedani et al. 2018).

\subsection{Future research directions}

In addition to the directions for future research derived from our study's limitations, we offer scholars other promising lines of enquiry. First, future research could explore growth in terms of international sales or other dimensions of performance such as new product and service development. We expect that such performance criteria may also require constellations of greater economic freedom. Second, scholars could look at the dynamic coevolution process, treating certain regulatory policy changes or monetary instability as an exogenous shock, and then thoroughly investigating the linkages between policies and outcomes. Scholars have begun to examine individual country cases, for example, the history of innovation policy in Sweden (Karlson et al. 2020), but there is a need for detailed multi-country research. The differences between developed and developing countries can be explored in this respect. Third, scholars should explore subnational levels as some regions may offer more favorable conditions to women entrepreneurs due to policies or ecosystems. Fourth, researchers could investigate how components of economic freedom may disproportionately affect other subgroups of entrepreneurs such as immigrants and minorities. Lastly, it is important to look into other relevant formal institutions such as taxation and intellectual property protection and their influence on women entrepreneurs' growth ambitions. 


\section{Appendix}

Fig. 1 Plots of cross-level interactions of regulatory efficiency and entrepreneurship
Lagged business freedom * male entrepreneurship

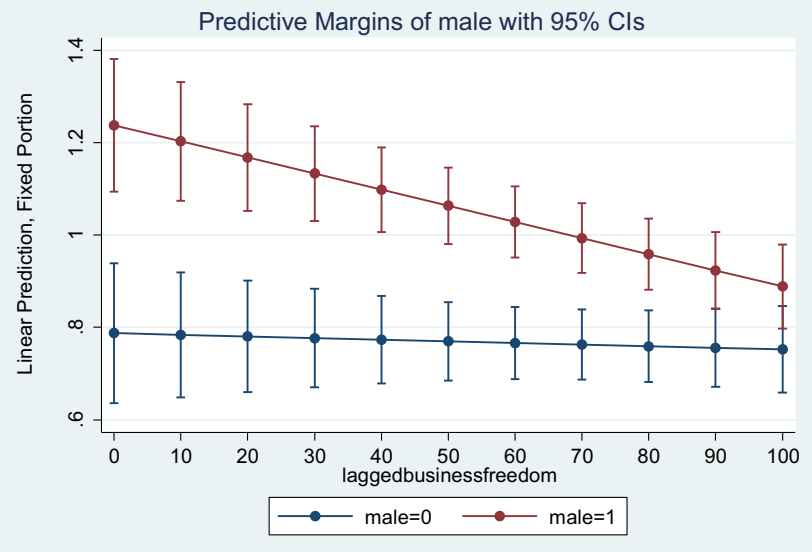

Lagged labor freedom * male entrepreneurship

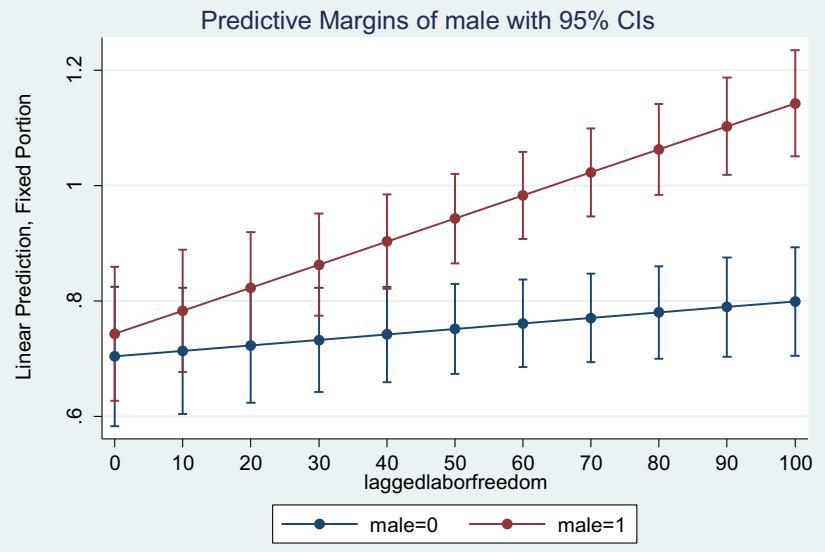

Lagged monetary freedom * male entrepreneurship

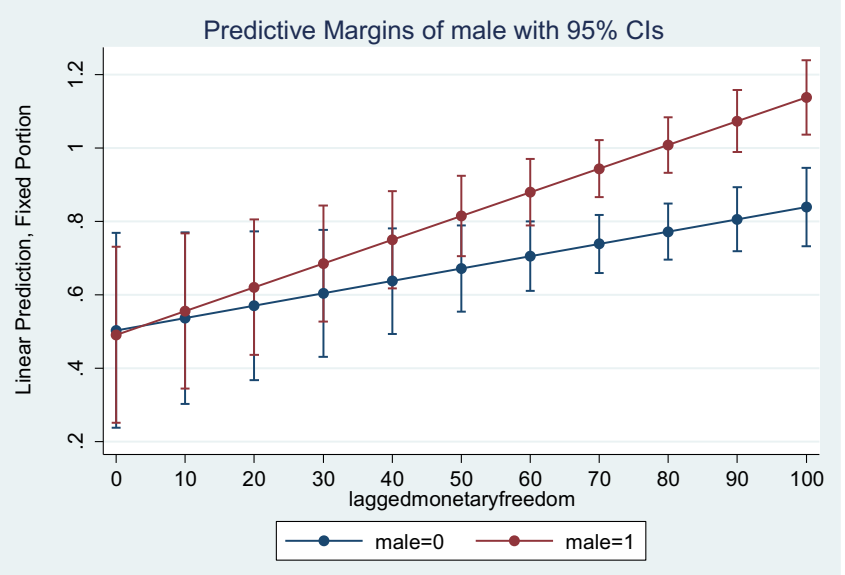


Open Access This article is licensed under a Creative Commons Attribution 4.0 International License, which permits use, sharing, adaptation, distribution and reproduction in any medium or format, as long as you give appropriate credit to the original author(s) and the source, provide a link to the Creative Commons licence, and indicate if changes were made. The images or other third party material in this article are included in the article's Creative Commons licence, unless indicated otherwise in a credit line to the material. If material is not included in the article's Creative Commons licence and your intended use is not permitted by statutory regulation or exceeds the permitted use, you will need to obtain permission directly from the copyright holder. To view a copy of this licence, visit http://creativecommons.org/licenses/by/4.0/.

\section{References}

Acemoglu, D. (2001). Good jobs versus bad jobs. Journal of Labor Economics, 19(1), 1-21. https://doi.org/10.1086 /209978.

Aghion, P., Fally, T., \& Scarpetta, S. (2007). Credit constraints as a barrier to the entry and post-entry growth of firms. Economic Policy, 22(52), 731-779. https://doi.org/10.1111 /j.1468-0327.2007.00190.x.

Ahl, H., \& Nelson, T. (2015). How policy positions women entrepreneurs: a comparative analysis of state discourse in Sweden and the United States. Journal of Business Venturing, 30(2), 273-291. https://doi.org/10.1016/j. jbusvent.2014.08.002.

Aidis, R., Estrin, S., \& Mickiewicz, T. (2012). Size matters: entrepreneurial entry and government. Small Business Economics, 39(1), 119-139. https://doi.org/10.1007 /s11187-010-9299-y.

Alsos, G. A., Isaksen, E. J., \& Ljunggren, E. (2006). New venture financing and subsequent business growth in men- and women-led businesses. Entrepreneurship Theory and Practice 30, 669-686. 10.1111\%2Fj.1540-6520.2006.00141.x.

Aparicio, S., Urbano, D., \& Audretsch, D. (2016). Institutional factors, opportunity entrepreneurship and economic growth: panel data evidence. Technological Forecasting and Social Change, 102, 45-61. https://doi.org/10.1016/j. techfore.2015.04.006.

Ardagna, S., Lusardi, A. (2008). Explaining international differences in entrepreneurship: the role of individual characteristics and regulatory constraints. NBER Working Paper Series, No. 14012. https://doi.org/10.3386/w14012

Arshed, N., Carter, S., \& Mason, C. (2014). The ineffectiveness of entrepreneurship policy: is policy formulation to blame? Small Business Economics, 43(3), 639-659. https://doi. org/10.1007/s11187-014-9554-8.

Autio, E., \& Acs, Z. (2010). Intellectual property protection and the formation of entrepreneurial growth aspirations. Strategic Entrepreneurship Journal, 4(3), 234-251. https://doi. org/10.1002/sej.93.

Autio, E., \& Fu, K. (2015). Economic and political institutions and the entry into formal and informal entrepreneurship. Asia Pacific Journal of Management, 32(1), 67-94. https://doi. org/10.1007/s10490-014-9381-0.
Autio, E., Pathak, S., \& Wennberg, K. (2013). Consequences of cultural practices for entrepreneurial behaviors. Journal of International Business Studies, 44(4), 334-362. https://doi. org/10.1057/jibs.2013.15.

Bardasi, E., Sabarwal, S., \& Terrell, K. (2011). How do female entrepreneurs perform? Evidence from three developing regions. Small Business Economics, 37, 417-441. https://doi. org/10.1007/s11187-011-9374-z.

Batjargal, B., Hitt, M. A., Tsui, A. S., Arregle, J. L., Webb, J. W., \& Miller, T. L. (2013). Institutional polycentrism, entrepreneurs' social networks, and new venture growth. Academy of Management Journal, 56, 1024-1049. https://doi. org/10.5465/amj.2010.0095.

Baumol, W. J. (1990). Entrepreneurship: productive, unproductive, and destructive. Journal of Political Economy, 98(5), 893-921. https://doi.org/10.1016/0883-9026(94)00014-x.

Baumol, W. J., Litan, R. E., \& Schramm, C. J. (2007). Good capitalism, bad capitalism and the economics of growth and prosperity. New Haven: Yale University Press. https://doi. org/10.2139/ssrn.985843.

Becker-Blease, J. R., \& Sohl, J. E. (2007). Do women-owned businesses have equal access to angel capital? Journal of Business Venturing, 22(4), 503-521. https://doi.org/10.1016 /j.jbusvent.2006.06.003.

Bjornskov, C., \& Foss, N. J. (2010). Do economic freedom and entrepreneurship impact total factor productivity? SMG Working Paper No. 8. https://doi.org/10.2139/ssrn.1683965.

Bjornskov, C., \& Foss, N. J. (2016). Institutions, entrepreneurship, and economic growth: what do we know and what do we still need to know? Academy of Management Perspectives, 30(3), 292-315. https://doi.org/10.5465/amp.2015.0135.

Block, J., \& Landgraf, A. (2016). Transition from part-time entrepreneurship to full-time entrepreneurship: the role of financial and non-financial motives. International Entrepreneurship and Management Journal, 12(1), 259282. https://doi.org/10.1007/s11365-014-0331-6.

Block, J. H., Fisch, C. O., Lau, J., Obschonka, M., \& Presse, A. (2019). How do labor market institutions influence the preference to work in family firms? A multilevel analysis across 40 countries. Entrepreneurship Theory and Practice, 43(6), 1067-1093. https://doi.org/10.1177/1042258718765163.

Boden, R. J., \& Nucci, A. R. (2000). On the survival prospects of men's and women's new business ventures. Journal of Business Venturing, 15(4), 347-362. https://doi.org/10.1016 /S0883-9026(98)00004-4.

Boudreaux, C. J., Nikolaev, B. N., \& Klein, P. (2019). Sociocognitive traits and entrepreneurship: the moderating role of economic institutions. Journal of Business Venturing, 34(1), 178-196. https://doi.org/10.1016/j.jbusvent.2018.08.003.

Bowen, H., \& De Clercq, D. (2008). Institutional context and the allocation of entrepreneurial efforts. Journal of International Business Studies, 39(4), 747-767. https://doi.org/10.1057 /palgrave.jibs.8400343.

Bradley, S. W., \& Klein, P. (2016). Institutions, economic freedom, and entrepreneurship: the contribution of management scholarship. Academy of Management Perspectives, 30(3), 211-221. https://doi.org/10.5465/amp.2013.0137.

Branstetter, L., Lima, F., Taylor, L. J., \& Venâncio, A. (2014). Do entry regulations deter entrepreneurship and job creation? Evidence from recent reforms in Portugal. The Economic 
Journal, 124(577), 805-832. https://doi.org/10.1111 /ecoj.12044.

Braunerhjelm, P., \& Eklund, J. E. (2014). Taxes, tax administrative burdens and new firm formation. Kyklos, 67(1), 1-11. https://doi.org/10.1111/kykl.12040.

Brush, C. G., Carter, N. M., Gatewood, E. J., Greene, P. G., \& Hart, M. M. (2006). The use of bootstrapping by women entrepreneurs in positioning for growth. Venture Capital, 8(1), 15-31. https://doi.org/10.1080/13691060500433975.

Brush, C. G., \& Cooper, S. Y. (2012). Female entrepreneurship and economic development: an international perspective. Entrepreneurship and Regional Development, 24(1-2), 16. https://doi.org/10.1080/08985626.2012.637340.

Brush, C. G., de Bruin, A., \& Welter, F. (2009). A gender-aware framework for women's entrepreneurship. International Journal of Gender and Entrepreneurship, 1(1), 8-24. https://doi.org/10.1108/17566260910942318.

Brush, C., Edelman, L. F., Manolova, T., \& Welter, F. (2019). A gendered look at entrepreneurship ecosystems. Small Business Economics, 53, 393-408. https://doi.org/10.1007 /s11187-018-9992-9.

Bullough, A., Renko, M., \& Abdelzaher, D. (2017). Women's business ownership: operating within the context of institutional and in-group collectivism. Journal of Management, 43(7), 2037-2064. https://doi.org/10.1177 /0149206314561302.

Cassar, G. (2004). The financing of business start-ups. Journal of Business Venturing, 19(2), 261-283. https://doi.org/10.1016 /S0883-9026(03)00029-6.

Chowdhury, F., Audretsch, D., \& Belitski, M. (2019). Institutions and entrepreneurship quality. Entrepreneurship Theory and Practice., 43(1), 51-81. https://doi.org/10.1177 $/ 1042258718780431$

Coad, A., Nielsen, K., \& Timmermans, B. (2017). My first employee: an empirical investigation. Small Business Economics, 48(1), 25-45. https://doi.org/10.1007/s11187016-9748-3.

Coleman, S., Henry, C., Orser, B., Foss, L., \& Welter, F. (2019). Policy support for women entrepreneurs' access to financial capital: evidence from Canada, Germany, Ireland, Norway, and the United States. Journal of Small Business Management, 57(52), 296-322. https://doi.org/10.1111 jjsbm. 12473.

Coleman, S., \& Robb, A. M. (2012). A rising tide: financing strategies for women-owned firms. Stanford: Stanford University Press.

Cuervo-Cazurra, A., Mudambi, R., \& Pedersen, T. (2019). Clarifying the relationships between institutions and global strategy. Global Strategy Journal, 9, 151-175. https://doi. org/10.1002/gsj.1342.

Danakol, S. H., Estrin, S., Reynolds, P., \& Weitzel, U. (2017). Foreign direct investment via M\&A and domestic entrepreneurship: blessing or curse? Small Business Economics, 48(3), 599-612. https://doi.org/10.1007/s11187-016-9792-z.

Darnihamedani, P., Block, J. H., Hessels, J., \& Simonyan, A. (2018). Start-up costs, taxes, and innovative entrepreneurship. Small Business Economics, 51(2), 355-369. https://doi.org/10.1007/s11187-018-0005-9.

Daunfeldt, S., Elert, N., \& Johansson, D. (2015). Are high-growth firms overrepresented in high-tech industries? Industrial and
Corporate Change, 25(1), 1-21. https://doi.org/10.1093 /icc/dtv035.

Davis, A., \& Shaver, K. (2012). Understanding gender variations in business growth intentions across the life course. Entrepreneurship Theory and Practice 36, 495-512. 10.1111 \%2Fj.1540-6520.2012.00508.x.

Devine, R. A., Molina-Sieiro, G., Holmes, R. M., \& Terjesen, S. A. (2019). Female-led high-growth: examining the role of human and financial resources management. Journal of Small Business Management, 57(1), 81-109. https://doi. org/10.1111/jsbm.12492.

Díaz-Casero, J. C., Díaz-Aunión, A. M., Sánchez-Escobedo, M. C., Coduras, A., \& Hernández-Mogollón, R. (2012). Economic freedom and entrepreneurial activity. Management Decision, 50(9), 1686-1711. https://doi. org/10.1108/00251741211266750.

DiLorenzo, T. J. (2004). How capitalism saved America. New York: Crown Forum.

Eesley, C. (2016). Institutional barriers to growth: entrepreneurship, human capital and institutional change. Organization Science, 27(5), 1065-1341. https://doi.org/10.1287 /orsc.2016.1077.

Efendic, A., Mickiewicz, T., \& Rebmann, A. (2015). Growth aspirations and social capital: young firms in a post-conflict environment. International Small Business Journal 33(5), 537-561. 10.1177\%2F0266242613516987.

Eisenhardt, K. M., \& Martin, J. A. (2000). Dynamic capabilities: what are they? Strategic Management Journal, 21(10), 1105-1121. https://doi.org/10.1002/1097-0266(200010/11 21:10/11\%3C1105::AID-SMJ133\%3E3.0.CO;2-E.

Elam, A. B., Brush, C. G., Greene, P. G., Baumer, B., Dean, M. \& Heavlow, R. (2019). GEM Women's Entrepreneurship 2018/ 2019 Report (2019). Available at: https://www. gemconsortium.org/. .

Estrin, S., Korosteleva, J., \& Mickiewicz, T. (2013). Which institutions encourage entrepreneurial growth aspirations? Journal of Business Venturing, 28, 564-580. https://doi. org/10.1016/j.jbusvent.2012.05.001.

Estrin, S., \& Mickiewicz, T. (2011). Institutions and female entrepreneurship. Small Business Economics, 37, 397-415. https://doi.org/10.1007/s11187-011-9373-0.

Estrin, S., Mickiewicz, T., \& Stephan, U. (2016). Human capital in social and commercial entrepreneurship. Journal of Business Venturing, 31(4), 449-467. https://doi.org/10.1016/j. jbusvent.2016.05.003.

Fairlie, R. W., \& Robb, A. M. (2009). Gender differences in business performance: evidence from the characteristics of business owners survey. Small Business Economics, 33, 375-395. https://doi.org/10.1007/s11187-009-9207-5.

Ferraz, C., Finan, F., Szerman, D. (2015). Procuring firm growth: the effects of government purchases on firm dynamics. NBER Working Paper Series, No. 21219. https://doi. org/10.3386/w21219.

Fisher, G., Kuratko, D. F., Bloodgood, J. M., \& Hornsby, J. S. (2017). Legitimate to whom? The challenge of audience diversity and new venture legitimacy. Journal of Business Venturing, 32(1), 52-71. https://doi.org/10.1016/j. jbusvent.2016.10.005.

Foss, L., Henry, C., Ahl, H., \& Mikalsen, G. H. (2019). Women's entrepreneurship policy research: a 30-year review of the 
evidence. Small Business Economics, 53, 409-429. https://doi.org/10.1007/s11187-018-9993-8.

Friedman, M. (1962). Should there be an independent monetary authority? In L. B. Yeager (Ed.), In search of a monetary constitution. Cambridge, MA: Harvard University Press.

Friedman, M. (1977). Noble lecture: inflation and unemployment. Journal of Political Economy, 85(3), 451-472.

Goltz, S., Buche, M. W., \& Pathak, S. (2015). Political empowerment, rule of law, and women's entry into entrepreneurship. Journal of Small Business Management, 53(3), 605-626. https://doi.org/10.1111/jsbm.12177.

Grilli, L., \& Murtinu, S. (2014). Government, venture capital and the growth of European high-tech entrepreneurial firms. Research Policy, 43(9), 1523-1543. https://doi.org/10.1016 /j.respol.2014.04.002.

Gwartney, J., Lawson, R., \& Norton, S. (2008). Economic Freedom of the World: (2008). Annual Report. Toronto, Canada: Economic Freedom Network.

Hart, O. (2009). Regulation and Sarbanes-Oxley. Journal of Accounting Research, 47(2), 437-445. https://doi. org/10.1111/j.1475-679X.2009.00329.x.

Hechavarria, D. M., Bullough, A., Brush, C., \& Edelman, L. (2019). High-growth women's entrepreneurship: fueling social and economic development. Journal of Small Business Management, 57(1), 5-13. https://doi.org/10.1111 jjsbm.12503.

Heck, R. H., Thomas, S. L., \& Tabata, L. (2010). Multilevel and longitudinal analysis using SPSS. New York, NY: Routledge/Taylor \& Francis.

Heirman, A., \& Clarysse, B. (2004). How and why do researchbased start-ups differ at founding? A resource-based configurational perspective. Journal of Technology Transfer, 29, 247-268. ht tps://doi.org/10.1023 /B:JOTT.0000034122.88495.0d.

Henrekson, M., \& Sanandaji, T. (2011). Entrepreneurship and the theory of taxation. Small Business Economics, 37, 167-185. https://doi.org/10.1007/s11187-009-9242-2.

Heritage Foundation. (2008). Index of Economic Freedom. Retrieved June 14, 2019 from: http:// thf_media.s3.amazonaws.com/index/pdf/2008/ Index2008_Chapter4.pdf

Hessels, J., Gelderen, M., \& Thurik, R. (2008). Entrepreneurial aspirations, motivations, and their drivers. Small Business Economics, 31(3), 323-339. https://doi.org/10.1007 /s11187-008-9134-x.

Hofmann, D. A., Griffin, M. A., \& Gavin, M. B. (2000). The application of hierarchical linear modeling to organizational research. In K. J. Klein \& S. W. J. Kozlowski (Eds.), Multilevel theory, research, and methods in organizations: foundations, extensions, and new directions (pp. 467-511). San Francisco, CA: Jossey-Bass.

Holmlund, B. (2014). What do labor market institutions do? Labour Economics, 30, 62-69. https://doi.org/10.1016/j. labeco.2014.06.007.

Holmes, R. M., Miller, T. \& Hitt, M. A. (2013). The interrelationships among informal institutions, formal institutions, and inward foreign direct investment. Journal of Management 39(2), 531-566. 10.1177\%2F0149206310393503.

Jennings, J. E., \& Brush, C. G. (2013). Research on women entrepreneurs: challenges to (and from) the broader entrepreneurship literature? Academy of Management Annals, 7(1), 663-715. https://doi.org/10.1080 /19416520.2013.782190.

Kaplan, D. S., Piedra, E., \& Seira, E. (2011). Entry regulation and business start-ups: evidence from Mexico. Journal of Public Economics, 95(11-12), 1501-1515. https://doi.org/10.1596 /1813-9450-4322.

Kanze, D., Huang, L., Conley, M. A., \& Higgins, E. T. (2018). We ask men to win and women not to lose: closing the gender gap in startup funding. Academy of Management Journal, 61(2), 586-614. https://doi.org/10.5465/amj.2016.1215.

Karlson, N., Sandström, C. \& Wennberg, K. (2020). Bureaucrats or markets in innovation policy? A critique of the entrepreneurial state. The Review of Austrian Economics. https://doi. org/10.1007/s11138-020-00508-7.

Kelley, D. J., Baumer, B. S., Brush, C., Greene, P. J., Mahdavi, M., Majbouri, M., Cole, M., Dean, M., \& Heavlow, R. (2017). Global Entrepreneurship Monitor women's entrepreneurship 2016/2017. Available at http://gemconsortium.org/. Retr July 1, 2020.

Khaire, M. (2010). Young and no money? Never mind: the material impact of social resources on new venture growth. Organization Science, 21(1), 168-185. https://doi. org/10.1287/orsc. 1090.0438 .

Koellinger, P., Minniti, M., \& Schade, C. (2007). "I think I can, I think I can": overconfidence and entrepreneurial behavior. Journal of Economic Psychology, 28(4), 502-527. https://doi.org/10.1016/j.joep.2006.11.002.

Kuckertz, A., Berger, E. S. C., \& Mpeqa, A. (2016). The more the merrier? Economic freedom and entrepreneurial activity. Journal of Business Research, 69(4), 1288-1293. https://doi.org/10.1016/j.jbusres.2015.10.094.

Lechner, C., \& Kreutzer, M. (2010). Coordinating growth initiatives in multi-unit firms. Long Range Planning, 43(1), 6-32. https://doi.org/10.1016/j.lrp.2009.10.002.

Levie, J., \& Autio, E. (2011). Regulatory burden, rule of law, and entry of strategic entrepreneurs: an international panel study. Journal of Management Studies, 48(6), 1392-1419. https://doi.org/10.1111/j.1467-6486.2010.01006.x.

Li, C., Isidor, R., Dau, L. A., \& Kabst, R.(2018). The more the merrier? Immigrant share and entrepreneurial activities. Entrepreneurship Theory and Practice 42(5), 698-733. $10.1177 \%$ 2F 1042258718795344

Link, A. N., \& Strong, D. R. (2016). Gender and entrepreneurship: an annotated bibliography. Foundations and Trends in Entrepreneurship, 12(4-5), 287-441. https://doi. org/10.1561/0300000068.

Mainiero, L. A., \& Sullivan, S. E. (2005). Kaleidoscope careers: an alternate explanation for the "opt-out" revolution. Academy of Management Perspectives, 19(1), 106-123. https://doi.org/10.5465/ame.2005.15841962.

McAdam, M., Harrison, R. T., \& Leitch, C. M. (2019). Stories from the field: women's networking as gender capital in entrepreneurial ecosystems. Small Business Economics, 53, 459-474. https://doi.org/10.1007/s11187-018-9995-6.

McMullen, J., Bagby, R., \& Palich, R. (2008). Economic freedom and the motivation to engage in entrepreneurial action. Entrepreneurship Theory and Practice., 32, 875-895. https://doi.org/10.1111/j.1540-6520.2008.00260.x.

Mueller, S., \& Thomas, A. S. (2001). Culture and entrepreneurial potential: a nine country study of locus of control and 
innovativeness. Journal of Business Venturing, 16(1), 51-75. https://doi.org/10.1016/S0883-9026(99)00039-7.

Nikolaev, B. N., Boudreaux, C. J., \& Palich, L. (2018). Crosscountry determinants of early-stage necessity and opportunity-motivated entrepreneurship: accounting for model uncertainty. Journal of Small Business Management, 56(1), 243-280. https://doi.org/10.1111/jsbm.12400.

North, D. C. (1990). Institutions, institutional change and economic performance. Cambridge: Cambridge University Press.

Pan, Y., \& Sparks, J. R. (2012). Predictors, consequence, and measurement of ethical judgments: review and meta-analysis. Journal of Business Research, 65(1), 84-91. https://doi. org/10.1016/j.jbusres.2011.02.002.

Parker, S. C. (2018). The economics of entrepreneurship (2nd ed.). Cambridge: Cambridge University Press.

Penrose, E. (1959). The theory of the growth of the firm. New York, NY: Oxford Univ. Press.

Pergelova, A., Manolova, T., Simeonova-Galeva, R., \& Yordanova, D. (2019). Democratizing entrepreneurship? Digital technologies and the internationalization of femaleled SMEs. Journal of Small Business Management, 57(1), 14-39. https://doi.org/10.1111/jsbm.12494.

Peterson, M. F., Arregle, J.-L., \& Martin, X. (2012). Multilevel models in international business research. Journal of International Business Studies, 43, 451-457. https://doi. org/10.1057/jibs.2011.59.

Powell, M., \& Ansic, D. (1997). Gender differences in risk behaviour in financial decision-making: an experimental analysis. Journal of Economic Psychology, 18(6), 605-628. https://doi.org/10.1016/S0167-4870(97)00026-3.

Reynolds, P., Bosma, N., Autio, E., Hunt, S., De Bono, N., Servais, I., \& Chin, N. (2005). Global Entrepreneurship Monitor: data collection design and implementation 19982003. Small Business Economics, 24(3), 205-231. https://doi.org/10.1007/s11187-005-1980-1.

Rosenbaum, G. O. (2017). Female entrepreneurial networks and foreign market entry. Journal of Small Business and Enterprise Development, 24(1), 119-135. https://oi. org/10.1108/JSBED-07-2016-0113.

Rostam-Afschar, D. (2014). Entry regulation and entrepreneurship: a natural experiment in German craftsmanship. Empirical Economics, 47(3), 1067-1101. https://doi. org/10.1007/s00181-013-0773-7.

Schumpeter, J. A. (1934). The theory of economic development. Cambridge, MA: Harvard University Press.

Sexton, D. L., \& Bowman-Upton, N. (1990). Female and male entrepreneurs: psychological characteristics and their role in gender-related discrimination. Journal of Business Venturing, 5(1), 29-36. https://doi.org/10.1016/0883-9026 (90)90024-N.

Shepherd, D. A., Williams, T. A., \& Patzelt, H. (2015). Thinking about entrepreneurial decision making: review and research agenda. Journal of Management 41(1), 11-46. 10.1177 $\% 2 \mathrm{~F} 0149206314541153$.

Shleifer, A. (2010). Efficient regulation. NBER Working Paper Series, No. 15651. http://www.nber.org/papers/w15651

Siebert, H. (1997). Labor market rigidities: at the root of unemployment in Europe. Journal of Economic Perspectives, 11(3), 37-54. https://doi.org/10.1257/jep.11.3.37.
Smith, N. R., \& Miner, J. B. (1983). Type of entrepreneur, type of firm, and managerial motivation: implications for organizational life cycle theory. Strategic Management Journal, 4(4), 325-340. https://doi.org/10.1002/smj.4250040404.

Sperber, S., \& Linder, C. (2019). Gender-specifics in startup strategies and the role of the entrepreneurial ecosystems. Small Business Economics, 53, 533-546. https://doi. org/10.1007/s11187-018-9999-2.

Stam, E., \& Wennberg, K. (2009). The roles of R\&D in new firm growth. Small Business Economics, 33(1), 77-89. https://doi. org/10.1007/s11187-009-9183-9.

Stephan, U., Uhlaner, L. M., \& Stride, C. (2015). Institutions and social entrepreneurship: the role of institutional voids, institutional support, and institutional configurations. Journal of International Business Studies, 46, 308-331. https://doi. org/10.1057/jibs.2014.38.

Sternberg, R., \& Wennekers, S. (2005). Determinants and effects of new business creation using Global Entrepreneurship Monitor Data. Small Business Economics, 24(3), 193-203. https://doi.org/10.1007/s11187-005-1974-z.

Teece, D. (2007). Explicating dynamic capabilities: the nature and microfoundations of (sustainable) enterprise performance. Strategic Management Journal, 28(13), 1319-1350. https://doi.org/10.1002/smj.640.

Terjesen, S., Bosma, N., \& Stam, E. (2016). Advancing public policy for high-growth, female and social entrepreneurs. Public Administration Review, 76(2), 230-239. https://doi. org/10.1111/puar.12472.

Thébaud, S. (2015). Business as plan B: institutional foundations of gender inequality in entrepreneurship across 24 industrialized countries. Administrative Science Quarterly 60(4), 671-711. 10.1177\%2F0001839215591627.

Tonoyan, V., Strohmeyer, R., \& Jennings, J. E. (2020). Gender gaps in perceived startup ease: implications of sex-based labor market segregation for entrepreneurship across 22 European countries. Administrative Science Quarterly, 65(1), 181-225. https://doi.org/10.1177 /0001839219835867.

Tversky, A., \& Kahneman, D. (1992). Advances in prospect theory: cumulative representation of uncertainty. Journal of Risk and Uncertainty, 5(4), 297-323. https://doi.org/10.1007 /BF00122574.

Ucbasaran, D., Westhead, P., Wright, M., \& Flores, M. (2010). The nature of entrepreneurial experience, business failure and comparative optimism. Journal of Business Venturing, 25, 541-555. https://doi.org/10.1016/j.jbusvent.2009.04.001.

Unger, J. M., Rauch, A., Frese, M., \& Rosenbusch, N. (2011). Human capital and entrepreneurial success: a meta-analytical review. Journal of Business Venturing, 26(3), 341-358. https://doi.org/10.1016/j.jbusvent.2009.09.004.

Valdez, M. E., \& Richardson, J. (2013). Institutional determinants of macro-level entrepreneurship. Entrepreneurship Theory and Practice 37(5), 1149-1175. 10.1111\%2Fetap.12000.

Van Staveren, I. (2014). The Lehman sisters hypothesis. Cambridge Journal of Economics, 38(5), 995-1014. https://doi.org/10.1093/cje/beu010.

Van Stel, A., Storey, D. J., \& Thurik, A. R. (2007). The effect of business regulations on nascent and young business entrepreneurship. Small Business Economics, 28(2-3), 171-186. https://doi.org/10.1007/s11187-006-9014-1. 
Vecchione, M., Caprara, G., Schoen, H., Castro, J. L. G., \& Schwartz, S. H. (2012). The role of personal values and basic traits in perceptions of consequences of immigration: a threenation study. British Journal of Psychology, 103(3), 359377. https://doi.org/10.1111/j.2044-8295.2011.02079.x.

Verheul, I., \& Thurik, R. (2001). Start-up capital: does gender matter? Small Business Economics, 16(4), 329-346. https://doi.org/10.1023/A:1011178629240.

Verheul, I., Uhlaner, L., \& Thurik, R. (2005). Business accomplishments, gender and entrepreneurial self-image. Journal of Business Venturing, 20(4), 483-518. https://doi.org/10.1016 /j.jbusvent.2004.03.002.

Watson, J., \& Robinson, S. (2003). Adjusting for risk in comparing the performances of male- and female-controlled SME. Journal of Business Venturing, 18(6), 773-788. https://doi. org/10.1016/S0883-9026(02)00128-3.

Welter, F., Baker, T., Audretsch, D., \& Gartner, W. B. (2017). Everyday entrepreneurship: a call for entrepreneurship research to embrace entrepreneurial diversity. Entrepreneurship Theory and Practice 41(3), 311-321. 10.1111\%2Fetap. 12258.

Williamson, O. (1996). The mechanisms of governance. New York: Oxford University Press.

Wong, P. K., Ho, Y. P., \& Autio, E. (2005). Entrepreneurship, innovation and economic growth: evidence from GEM data. Small Business Economics, 24(3), 335-335. https://doi. org/10.1007/s11187-005-2000-1.

World Bank. (2017). Cluster brief: improving regulatory efficiency for firms. http://pubdocs.worldbank.org/en/661901511197046271 /ComPEL-ClusterBrief-Ref-Efficiency-4-Firms-Jul17.pdf. Accessed 28 May 2020.

Publisher's note Springer Nature remains neutral with regard to jurisdictional claims in published maps and institutional affiliations. 